\title{
Tray Drying Characteristics of Onion Slices and Physicochemical Analysis of Dried Onion Powder
}

\author{
Ravi Dutt Shukla*, Anurag Patel and Avanish Kumar
}

Department of Food Process Engineering, Vaugh Institute of Agricultural Engineering and Technology, SHUATS, Allahabad- 211007 (Uttar Pradesh) India

*Corresponding author

\begin{tabular}{|c|c|}
\hline & A B S T R A C T \\
\hline & \multirow{3}{*}{$\begin{array}{l}\text { The present work was aimed to study the effect of pretreatments and drying temperatures } \\
\text { on quality and drying characteristic of onion slices in tray dryer and to study the effect of } \\
\text { drying air temperature }\left(1^{\text {st }} \text { stage drying at } 70,80,90^{\circ} \mathrm{C} \text { and } 2^{\text {nd }} \text { stage at } 60^{\circ} \mathrm{C}\right) \text { on onion } \\
\text { slices }(2,4 \text {, and } 6 \mathrm{~mm}) \text { also examine size, pretreatments water blanching and } 0.2,0.4,0.6 \\
\% \text { Potassium Metabisulphite on the quality of dried onion. Result of study showed that the } \\
\text { water blanched onion samples dried at } 90^{\circ} \mathrm{C}(6 \mathrm{~mm} \text { size }) \text { took least time to get dry. } \\
\text { Rehydration ratio was increased with increase in temperature. Potassium Metabisulphite } \\
\text { blanched sample dried at } 70^{\circ} \mathrm{C} \text { were better in nutritional quality. Quality of onion with } \\
\text { respect to colour, aroma and overall acceptability was better for } 0.6 \% \text { Potassium } \\
\text { Metabisulphite blanched onion samples dried at } 70^{\circ} \mathrm{C}\end{array}$} \\
\hline Article Info & \\
\hline $\begin{array}{l}\text { Accepted: } \\
17 \text { March } 2019 \\
\text { Available Online: } \\
10 \text { April } 2019\end{array}$ & \\
\hline
\end{tabular}

\section{Introduction}

India is one of the largest producers of the fruits and vegetables in the world with population close to 1.2 billion. Fruits and vegetables are very important for healthy living because they contain beneficial nutrients (Bates and oberts, 2001). Onion (Allium cepa) is widely used both for flavoring and for the potential benefits of preventing and curing ailments (Rivlin, 2001). Onion is also recommended because of its good nutritive value (Shekhad, 1996). Since ancient times, onion has been used worldwide as seasoning, spices and herbal remedies (Ahmed, 1997). Onion is known to possess a vast variety of biological functions such as antimicrobial (Kim, 2002; Krest et al., 2000) anti thrombotic (Block et al., 1986), and antioxidant (Furhath, 1997; Prasad et al., 1996; Siems et al., 1996). Onion is a perishable crop and it cannot store safely in normal condition for a long time. Under storage, onion bulbs continuously loose water and dry matter, but more serious losses arise from, sprouting and rooting (Annymous, Pandey, 1994). Blanching is an important heat process in the preparation of vegetables destined for canning, freezing or drying. Primarily blanching is carried out to inactivate enzymes or to destroy enzyme substrate such as peroxides. In addition to destroying enzymes, blanching also brings the changes as the raw material by destroying the bacterial load and cellular gases are expelled. To overcome the post-harvest losses of onion 
the drying of onion is one of the major processing operation which reduces the volume and there by transportation cost and increases the storage life of onion. Onion powder is a spice which is made by dried onion. The spice retains some of the pungency and flavor of fresh onions. The selection of dryer should be based on the entire manufacturing process, not only for the production capacity but also for initial moisture of the product, drying characteristics of the product and maximum allowable product temperature. Drying provokes a change of the physical, chemical and biological properties and modifies the characteristics of food products (Azzous et $a l$. , 2002). Therefore present investigation was undertaken to study the effect of different pretreatments (blanching with KMS and blanching with hot water) and drying temperatures $\left(70,80,90^{\circ} \mathrm{C}\right)$ on drying behavior, nutritional and sensory quality of dried onion.

The study it has revealed that onion contains four peptides (protein components) that inhibit angiotensin I-converting enzyme-the same enzyme blocked by ACE inhibitor drugs, which are used to lower blood pressure. When given to laboratory animals bred to be hypertensive, onion produced a blood pressure lowering effect within two to four hours. Animals have to eat just 20 to 30 $\mathrm{mg}$ of powerful spinach peptides for each kilogram (2.2 pounds) of their body weight. In human terms, an entrée-sized onion salad for lunch or a serving of steamed onion as part of the evening meal may have a salutary effect on blood pressure two to four hours later.

In view of above consideration, study was undertaken with the following objectives,

To study the effect of pretreatments and temperature on drying characteristics of onion slices.

To study the physicochemical characteristics of dried onion powder. To study the sensory characteristics of onion powder.

\section{Nutritive contents of onion (per $100 \mathrm{~g}$ )}

Energy $1.66 \mathrm{KJ}$ (40 Kcal), Carbohydrate 5.1g, Sugar $4.24 \mathrm{~g}$, Dietary fibers $0.6 \mathrm{~g}$, Fat $0.1 \mathrm{~g}$, Water $89.11 \mathrm{~g}$, Calcium 19mg, Vitamin C $7.4 \mathrm{mg}$, Protein 1.1g, Iron $0.21 \mathrm{mg}$, Magnesium 0.129mg, Phosphorus 29mg, Potassium 120mg, and Sodium 4mg (USDA Nutrient Database, 2001).

\section{Nutritive values of onion (per $100 \mathrm{~g}$ )}

Moisture 89.1\%, Protein 1.1g, Fat $0.1 \mathrm{~g}$, Carbohydrate $5.1 \mathrm{~g}$, Fiber $0.6 \mathrm{~g}$ and Calories 40 (USDA Nutrient Database, 2001).

\section{Materials and Methods}

The drying study of the onion powder was dried at three different temperature $(70,80$ and $90^{\circ} \mathrm{C}$ ) and $2^{\text {nd }}$ stage drying $60^{\circ} \mathrm{C}$ after 30 minute using tray drier. There are some parameters one onion variety, four pretreatments, three different temperature and three cut of three sizes of onion slices.

Onions were cleaned, peeled, sliced and blanched. Than tray dryer was used for the drying of onion slices. After drying, the slices were grinded in grinder and sieved through 32 mesh screens and packed in LDPE bags. Use for some of the equipment's, glassware and chemicals that were employed during the course of the study are given. 1. Electronic weighing balance, 2. Slicer, 3. Tray dryer, 4. Desiccators, 5. Hot Plate and 6. Sealing Machine,

\section{Preparation of onion powder}

There are several steps are used in preparation of onion powder, raw onion, washing, peeling 
(knife), slicing (2 mm, $4 \mathrm{~mm}, 6 \mathrm{~mm})$, blanched with KMS solution, drying in tray drier, temp. 70, 80 and $90^{\circ} \mathrm{C}$, second stage drying at $60^{\circ} \mathrm{C}$, grinding, sieving (32-mesh size screen), packaging (LDPE bags), storage.

\section{Physicochemical analysis}

\section{Moisture content of sample}

Moisture content during drying was computed through mass balance. For this purpose, weight of the sample during drying was recorded at time interval of every 30 minute.

M.C. $=\frac{\text { Wt. of sample at desired time - wt. of bone dry material }}{\text { Wt.of sample at any time }} x 100--$

Wt. of bone dried material $=$

$\frac{\text { Initial wt.of the sample } x 100-\text { initial M.C. }}{100}--E q$. (2)

\section{Dehydration ratio}

Dehydration ratio was calculated by taking the weights of sample before drying and the weight of sample after drying.

Rehydration Ratio $=\frac{W D}{W B}--E q \cdot(3)$

Where, WD = weight of the onion sample after drying, g, WB = weight of the onion sample before drying, $\mathrm{g}$

\section{Rehydration ratio}

The reconstitution or Rehydration ratio is one of the important bases to form a base material for further utilization. Dehydrated vegetables are rehydrated to study the reconstitution of dried sample. Rehydration ratio shows the originality gained and acceptability attribute of a product.

Procedure: $10 \mathrm{~g}$ samples of each were weighed. Placed in $600 \mathrm{ml}$ beaker, $150 \mathrm{ml}$ distilled water was added, it was covered and placed on electric heater, boiled for 25 minutes. The precise amount of water varies with material, time and rate of boiling, excessive amount of water should not be used. Removed from the heater and dumped into a funnel which was covered with a coarsely pour filter paper. Applied suction and drained with careful stirring for one min. or until the drop from the funnel has almost stopped. Remove from the funnel and weighed.

Calculation was made by using following formula to express the results in terms of 'Rehydration ratio'.

Rehydration Ratio

$$
=\frac{\text { Wt. of reconstituted rehydrated sample }(g)}{\text { Wt. of rehydrated sample }(g)}--E q .(4)
$$

\section{Determination of moisture content}

\section{Initial moisture content}

Standardization procedures of AOAC (1990) will be followed to estimate the moisture content of food.

Procedure: $05 \mathrm{~g}$ of the sample was weighted and placed in a tared porcelain dish $\mathrm{w}_{1}(\mathrm{~g})$. Dish was placed in hot air oven maintained at $105^{\circ} \mathrm{C} \pm 20$ and dried for at least two hours Dish was cooled in desiccators and weighed. The process of heating, cooling and weighing was repeated until the difference between two successive weighing was not more than 0.002 
g.

Observation
Tare weight of dish $\mathrm{w}(\mathrm{g})$.

Weight of dish with sample $\mathrm{W}_{1}(\mathrm{~g})$.

Weight of dish + sample after keeping in oven $\mathrm{W}_{2}(\mathrm{~g})$.

\section{Calculation}

Percent moisture content

$$
=\frac{\text { Loss in weight }}{\text { Initial weight of the sample }} \times 100-- \text { Eq. (5) }
$$

$\frac{W 1-W 2}{W 1-W} \times 100$

The moisture content of the sample was computed using the following equations.

Moisture content $($ wet basis $)=\frac{M 1-M 2}{M 1} \times 100--E q .(6)$

Moisture content $($ dry basis $)=\frac{\text { M.C. }(\text { wet basis })}{100-\text { M.C. }(\text { wet basis })} \times 100--E q .(7)$

M.C. (lost) = M.C. (Current) - M.C. (Previous)

Drying rate $=\left(\mathrm{W}_{\mathrm{t}}-\mathrm{W}_{\mathrm{t}+\mathrm{Dt}}\right) /\left(\mathrm{D}_{\mathrm{t}} * \mathrm{~W}_{\mathrm{d}}\right)--$ Eq. (8)

Where,

$\mathrm{W}_{\mathrm{t}}=$ Weight of sample at any time $\mathrm{t}, \mathrm{g} . \mathrm{W}_{\mathrm{t}+\mathrm{Dt}}$ $=$ Weight of sample at any time $\mathrm{t}+\mathrm{Dt}, \mathrm{g} . \mathrm{D}_{\mathrm{t}}=$ Time interval, minute. $\mathrm{W}_{\mathrm{d}}=$ Weight of bone dry material, g. M.C. = moisture content of sample (\% w.b. and \% d.b.). M.C. = moisture content of sample (\% w.b. and d.b.). $\mathrm{M}_{1}=\mathrm{wt}$. of sample before drying $(\mathrm{g}) \cdot \mathrm{M}_{2}=$ wt. of sample after drying $(\mathrm{g})$.

\section{Determination of ascorbic acid (Vitamin C)}

Ascorbic acid was determined by (Ranganna, 1986).

\section{Reagents used}

Standard Ascorbic Acid
2, 6 - dichlorophenol-indophenol dye indicator

$3 \%$ Meta phosphoric Acid

6\% Meta phosphoric Acid

Standardization of dye solution: $05 \mathrm{ml}$ of standard ascorbic acid solution was placed in a clean beaker to which $5 \mathrm{ml}$ of $3 \%$ metaphosphoric acid solution was added with the help of pipette. This solution was titrated against the dye till a faint pink colour appeared which persisted for not more than 15 seconds. Procedure: $30 \mathrm{~g}\left(\mathrm{~W}_{1}\right)$ of dehydrated onion blended with equal weight $\left(\mathrm{W}_{2}\right)$ of $6 \%$ met phosphoric acid for 3-4 minute $15 \mathrm{~g}\left(\mathrm{~W}_{3}\right)$ of this slurry was placed in $100 \mathrm{ml}\left(\mathrm{V}_{1}\right)$ volumetric flask and volume was made by adding 3\% met phosphoric acid. It was filtered through a fast filter paper. Burette was filled with standardized 2, 6-dichlorophenol indophenol's dye solution. $10 \mathrm{ml}$ of filter solution $\left(\mathrm{V}_{2}\right)$ was taken in conical flask and immediately titrated against the standard dye solution (V) till a faint pink colour will appear and persisted for 15 second.

\section{Calculation}

Calculated the ascorbic acid content in $\mathrm{mg} / 100 \mathrm{~g}$ of sample as follows

Ascorbic acid mg/100 =

$\frac{W 1+W 2}{W 1+W 3} \times \frac{V 1}{V 2} \times 100\left(V x \frac{1}{T}\right)--E q \cdot(9)$ 
Where,

$\mathrm{W}_{1}=$ weight of the sample (dried).

$\mathrm{W}_{2}=$ weight of $6 \%$ metaphosphoric acid.

$\mathrm{W}_{3}=$ weight of the slurry transferred in $\mathrm{ml}$ volumetric flask.

$\mathrm{V}_{1}=$ make up volume in volumetric flask.

$\mathrm{V}_{2}=\mathrm{ml}$ of dye indicator used in the titration.

$\mathrm{T}=$ litre value of dye with standard solution of vitamin $\mathrm{C}$.

\section{Total sugar and reducing sugar}

Total sugar and reducing sugar content in the sample was estimated by Lane and Eynon method (Ranganna, 1986). The estimated was based on the principal that the invert sugar reduced the copper in the Fehling's solution to red, insoluble cuprous oxide. The sugar content in the sample was estimated by determining the volume of the known sugar solution required to completely reduce a measured volume of Fehling' solution.

\section{Regents}

1. Fehling's solution (A): Dissolve $69.28 \mathrm{~g}$ of copper sulphate $\left(\mathrm{CUSO}_{4} .5 \mathrm{H}_{2} \mathrm{O}\right)$ in water, dilute to 1 liter.

2. Fehling's solution (B): Dissolve $346 \mathrm{~g}$ of potassium sodium tartrate and $100 \mathrm{~g} \mathrm{NaOH}$ in water and make up to 1 liter.

3. Methylene blue indicator: Dissolve $1 \mathrm{~g}$ of methylene blue in $100 \mathrm{ml}$ of water.

4. $45 \%$ Neutral lead acetate solution: Dissolve $225 \mathrm{~g}$ of Neutral lead acetate in water and dilute to $500 \mathrm{ml}$.

5. Standard invert sugar solution: Weigh $9.5 \mathrm{~g}$ of AR sucrose into a 1 liter volumetric flask and add $100 \mathrm{ml}$ water and $5 \mathrm{ml}$ of conc. HCL. Allow to stand for 3 days at $20-25^{\circ} \mathrm{C}$ for inversion to take place and make up to mark with water. Pipette $25 \mathrm{ml}$ of standard invert solution in to $100 \mathrm{ml}$ volumetric flask and add $50 \mathrm{ml}$ of water. Add a few drops of phenolphthalein indicator and neutralize with
$20 \% \mathrm{NaOH}$ until the solution turns pink. Acidify with $1 \mathrm{~N}$ HCL adding it drops wise with water.

\section{Preparation of sample}

Grind the sample and allow passing through 40-50 micron sieve. Take $50 \mathrm{~g}$ in a beaker and add $400 \mathrm{ml}$ of water. Neutralize the solution with $1 \mathrm{~N} \mathrm{NaOH}$ using phenolphthalein indicator. Boil gently for 1 hour with occasional stirring. Add boiling water to maintain original level. Cool and transfer to a $500 \mathrm{ml}$ volumetric flask. Make up to volume and filter through No. 4 Wattman Paper. Pipette a $100 \mathrm{ml}$ aliquot in to $500 \mathrm{ml}$ volumetric flask. Add $2 \mathrm{ml}$ neutral lead acetate solution and about $200 \mathrm{ml}$ water. Let it stand for 10 minute then precipitate the excess of lead with potassium oxalate solution. Make up to mark filter.

\section{Procedure (reducing sugar)}

i. Pipette $10 \mathrm{ml}$ mixed Fehling's solution in to each of two $250 \mathrm{ml}$ conical flask.

ii. Fill the $50 \mathrm{ml}$ burette with the solution to be titrated.

iii. Run in to the flask almost the whole volume of sugar solution required to reduce the Fehling's solution, so that 0.5 $\mathrm{ml}$ to $1.0 \mathrm{ml}$ is required later to complete the titration.

iv. Mix the contents of the flask, heat to boiling and boil moderately for 2 minute.

v. Add 3 drops of methylene blue solution, taking care not to allow touching the side of flask.

vi. Complete the titration with in 1 minute and add 2 to 3 drops of sugar solution at 5 to $10 \mathrm{sec}$ intervals, until the indicator is completely discolored.

vii. That boiling liquid assumed to be brick red color or precipitated cuprous oxide before adding the indicator.

viii. The volume of solution required. 


\section{Procedure (total sugar)}

1. Pipette $50 \mathrm{ml}$ of the clarified solution in to a $250 \mathrm{ml}$ conical flask.

2. Add $5 \mathrm{~g}$ of citric acid and $50 \mathrm{ml}$ of water.

3. Boil gently for 10 minute to complete the inversion of source and then cool.

4. Transfer to a $250 \mathrm{ml}$ volumetric flask and neutralize with $1 \mathrm{~N} \quad \mathrm{NaOH}$ using phenolphthalein as an indicator. Make up a volume.

5. Take an aliquot and determine the total sugar as invert sugar.

\section{Calculation}

$\%$ Reducing sugar $=\frac{m g \text { of invert sugar } X \text { Dilution } X 100}{\text { Titre } X \text { wt of the sample }}--E q .(10)$

$\%$ Total sugar as Invert sugar $=$

mg of invert sugar $X$ Dilution $X 100$

Titre $X$ wt of the sample

\section{Statistical analysis}

The experiment was conducted by adopting completely randomized design the data recorded during the course of investigation were statistically analyzed by the "Analysis of variance'. The significant effect of treatment was judged with the help of ' $F$ ' (variance ratio). Calculated $\mathrm{F}$ value was compared with the table value of $\mathrm{F}$ at $5 \%$ level of significance. If calculated value exceeded the table value the effect was considered to the significant. The significance of the study was tested at $5 \%$ level.

$$
\begin{array}{ll}
\mathrm{t} & =\mathrm{r}(\mathrm{n}-2) /\left(1-1 / 2^{2}\right) \\
\mathrm{SEd} & =2 \mathrm{EMSS} / \mathrm{r} \times \mathrm{t} \times \mathrm{s} \\
\mathrm{CD} & =\mathrm{SEd} \times \mathrm{t} 5 \% \text { at df }
\end{array}
$$

Where, $\mathrm{t}=$ distribution of observation, $\mathrm{r}=\mathrm{co}-$ efficient of correlation, $n=$ no. of observation,
$\mathrm{SEd}=$ standard error of difference, $\mathrm{d} . \mathrm{f}=$ error of degree of freedom, $\mathrm{CD}=$ critical difference and MESS= error mean sum of square.

\section{Results and Discussion}

These experiments were conducted to the tray drying characteristics of onion slices at different air temperature and pretreatment combinations. Dried onion slices were ground to powder in a domestic grinder. Onion powder samples were packed in LDPE bag. Studies on quality were based on physicochemical characteristics (Moisture content, Ascorbic acid content and Sugar). The physiochemical and sensory qualities were evaluated just after preparation of onion powder. On the basis of present investigation the following conclusions could be drawn. Drying rate of onion in Tray dryer was affected by hot air temperature. Higher drying rate at initial stage of drying decreases with time suggests decrease in moisture content with the passage of time.

The least final moisture content \% (w.b.) was found for water blanching at $90^{\circ} \mathrm{C}$ for $6 \mathrm{~mm}$, size (12.17) and maximum final moisture content $\%$ (w.b.) was found for $0.2 \%$ KMS blanched $70^{\circ} \mathrm{C}$ for $6 \mathrm{~mm}$, size (35.67). The drying rate of onion slices under tray drying decreased as the drying time progressed and finally attained zero drying rates. Low the dehydration ratio betters the process of drying. It is clear that $0.2 \% \mathrm{KMS}$ blanched sample dried at $90^{\circ} \mathrm{C}(6 \mathrm{~mm}$ size $)$ had the lowest dehydration ratio (0.105). Dehydration ratio for $0.2 \% \mathrm{KMS}$ blanched sample dried at $70^{\circ} \mathrm{C}(6 \mathrm{~mm}$ size $)$ had the highest dehydration ratio (0.157). Higher the dehydration ratio better was the quality of the product. Dehydration ratio refers to the extent of originality in product reached after the rehydration of dehydrated product. It is clear that $0.6 \% \mathrm{KMS}$ blanched sample dried at $90^{\circ} \mathrm{C}(2 \mathrm{~mm}$ size $)$ had the highest rehydration 
ratio (5.71). Rehydration ratio for water blanched sample dried at $70^{\circ} \mathrm{C}(6 \mathrm{~mm}$ size $)$ had the lowest rehydration ratio (4.03).The final vitamin $\mathrm{C}$ content in water blanched Sample was lower than the KMS blanched sample. In most of the cases ascorbic acid decreased with increasing temperature and time. Maximum ascorbic acid found $8.7,70^{\circ} \mathrm{C}$ (6mm size) $0.6 \% \mathrm{KMS}$ and minimum ascorbic acid was $6.01,90^{\circ} \mathrm{C}(2 \mathrm{~mm}$ size $)$ water blanching. Hence KMS treated sample showed a significant retention of vitamin $\mathrm{C}$ in the product. The final sugar content in water blanched Sample was lower than the KMS blanched sample. Maximum reducing sugar was $2.29,70^{\circ} \mathrm{C}$ (6mm size) $0.6 \% \mathrm{KMS}$ and minimum reducing sugar was $2.04,90^{\circ} \mathrm{C}$ ( $2 \mathrm{~mm}$ size) water blanching. Total score obtained for Overall acceptability evaluation on the basis of sensory evaluation was higher in drying of onion sample $0.4 \%$ KMS pretreatment and the sample dried at $70^{\circ} \mathrm{C}$ (4mm size) and maximum texture score was (7.39).

\section{Tray drying characteristics}

Onion slices were dried in tray dryer at air temperature first sage $70,80,90^{\circ \mathrm{C}}$ and $2^{\text {nd }}$ stage drying $60^{0 \mathrm{C}}$ to final equilibrium moisture content. The initial moisture content of onion slices was found to be $89.90 \%$ (w.b.) for each sample. The relationship between moisture content, drying time is shown in figure 1 to 2 .

Drying characteristics of water blanched onion sample (2 $\mathrm{mm}$ size): The water blanched onion sample dried at $70^{0 \mathrm{C}}$ air temperature, moisture content reduced to $22.23 \%$ (w.b.) at the end of 360 minute drying, for the same pretreatment and size, the moisture content at $80^{\circ \mathrm{C}}$ temperature moisture content was reduced to $14.04 \%$ (w.b.) at the end of 330 minute drying and $90^{\circ \mathrm{C}}$ temperature moisture content reduced to
$18.88 \%$ (w.b.) at the end of 300 minute drying. As shown in figure 1.

Drying characteristics of $0.2 \%$ KMS blanched onion sample ( $2 \mathrm{~mm}$ size): The $0.2 \% \mathrm{KMS}$ blanched onion sample dried at $70^{0 \mathrm{C}}$ air temperature, moisture content reduced to $28.86 \%$ (w.b.) at the end of 360 minute drying, for the same pretreatment and size, the moisture content at $80^{\circ \mathrm{C}}$ temperature moisture content reduced to $30.28 \%$ (w.b.) at the end of 330 minute drying and $90^{\circ \mathrm{C}}$ temperature moisture content reduced to $26.18 \%$ (w.b.) at the end of 300 minute drying. As shown in figure 2 .

Drying characteristics of $0.4 \%$ blanched onion sample (2 $\mathrm{mm}$ size): The $0.4 \%$ blanched onion sample dried at $70^{0 \mathrm{C}}$ air temperature, moisture content reduced to $22.60 \%$ (w.b.) at the end of 360 minute drying, for the same pretreatment and size, the moisture content at $80^{0 \mathrm{C}}$ temperature moisture content reduced to $22.31 \%$ (w.b.) at the end of 330 minute drying and $90^{0 \mathrm{C}}$ temperature moisture content reduced to $16.18 \%$ (w.b.) at the end of 300 minute drying. As shown in figure 3 .

Drying characteristics of $0.6 \%$ blanched onion sample (2 $\mathrm{mm}$ size): The $0.6 \%$ blanched onion sample dried at $70^{\circ \mathrm{C}}$ air temperature, moisture content reduced to $31.99 \%$ (w.b.) at the end of 360 minute drying, for the same pretreatment and size, the moisture content at $80^{0 \mathrm{C}}$ temperature moisture content was reduced to $30.58 \%$ (w.b.) at the end of 330 minute drying and $90^{\circ \mathrm{C}}$ temperature moisture content reduced to $12.93 \%$ (w.b.) at the end of 300 minute drying. As shown in figure 4.

Drying characteristics of water blanched onion sample (4 $\mathrm{mm}$ size): The initial moisture content of the onion slices was $89.90 \%$ (w.b.). As shown in figure 5. For 
water blanched onion sample dried at $70^{\circ} \mathrm{C}$ air temperature, moisture content reduced to $13.68 \%$ (w.b.) at the end of 360 minute drying, for the same pretreatment and size, the moisture content at $80^{\circ} \mathrm{C}$ temperature moisture content reduced to $20.78 \%$ (w.b.) at the end of 330 minute drying and $90^{\circ} \mathrm{C}$ temperature moisture content reduced to $25.74 \%$ (w.b.) at the end of 300 minute drying.

Drying characteristics of $0.2 \% \mathrm{KMS}$ blanched onion sample (4 $\mathrm{mm}$ size): The initial moisture content of the onion slices was $89.90 \%$ (w.b.). As shown in figure 6. For $0.2 \%$ KMS blanched onion sample dried at $70^{\circ} \mathrm{C}$ air temperature, moisture content reduced to $30.58 \%$ (w.b.) at the end of 360 minute drying, for the same pretreatment and size, the moisture content at $80^{\circ} \mathrm{C}$ temperature moisture content reduced to $32.21 \%$ (w.b.) at the end of 330 minute drying and $90^{\circ} \mathrm{C}$ temperature moisture content reduced to $27.34 \%$ (w.b.) at the end of 300 minute drying.

Drying characteristics of $0.4 \%$ KMS blanched onion sample (4 $\mathrm{mm}$ size): The initial moisture content of the onion slices was $89.90 \%$ (w.b.). As shown in figure 7. For $0.4 \%$ KMS blanched onion sample dried at $70^{\circ} \mathrm{C}$ air temperature, moisture content reduced to $26.01 \%$ (w.b.) at the end of 360 minute drying, for the same pretreatment and size, the moisture content at $80^{\circ} \mathrm{C}$ temperature moisture content reduced to $30.58 \%$ (w.b.) at the end of 330 minute drying and $90^{\circ} \mathrm{C}$ temperature moisture content reduced to $17.89 \%$ (w.b.) at the end of 300 minute drying.

Drying characteristics of $0.6 \%$ KMS blanched onion sample (4mm size): The initial moisture content of the onion slices was $89.90 \%$ (w.b.). As shown in figure 8. For $0.6 \% \mathrm{KMS}$ blanched onion sample dried at $70^{\circ} \mathrm{C}$ air temperature, moisture content reduced to $33.77 \%$ (w.b.) at the end of 360 minute drying, for the same pretreatment and size, the moisture content at $80^{\circ} \mathrm{C}$ temperature moisture content reduced to $31.29 \%$ (w.b.) at the end of 330 minute drying and $90^{\circ} \mathrm{C}$ temperature moisture content reduced to $16.53 \%$ (w.b.) at the end of 300 minute drying.

Drying characteristics of water blanched onion sample (6 $\mathrm{mm}$ size): The initial moisture content of the onion slices was $89.90 \%$ (w.b.). As shown in figure 9. For water blanched onion sample dried at $70^{\circ} \mathrm{C}$ air temperature, moisture content reduced to $16.87 \%$ (w.b.) at the end of 360 minute drying, for the same pretreatment and size, the moisture content at $80^{\circ} \mathrm{C}$ temperature moisture content reduced to $22.61 \%$ (w.b.) at the end of 330 minute drying and $90^{\circ} \mathrm{C}$ temperature moisture content reduced to $12.17 \%$ (w.b.) at the end of 300 minute drying.

Drying characteristics of $0.2 \%$ KMS blanched onion sample $(6 \mathrm{~mm}$ size $)$ : The initial moisture content of the onion slices was $89.90 \%$ (w.b.). As shown in figure 10. For $0.2 \% \mathrm{KMS}$ blanched onion sample dried at $70^{\circ} \mathrm{C}$ air temperature, moisture content reduced to $35.67 \%$ (w.b.) at the end of 360 minute drying, for the same pretreatment and size, the moisture content at $80^{\circ} \mathrm{C}$ temperature moisture content reduced to $33.77 \%$ (w.b.) at the end of 330 minute drying and $90^{\circ} \mathrm{c}$ temperature moisture content reduced to $28.11 \%$ (w.b.) at the end of 300 minute drying.

Drying characteristics of $0.4 \%$ KMS blanched onion sample (6 $\mathrm{mm}$ size): The initial moisture content of the onion slices was $89.90 \%$ (w.b.). As shown in figure 11. For $0.4 \%$ KMS blanched onion sample dried at $70^{\circ} \mathrm{C}$ air temperature, moisture content 
reduced to $30.10 \%$ (w.b.) at the end of 360 minute drying, for the same pretreatment and size, the moisture content at $80^{\circ} \mathrm{C}$ temperature moisture content reduced to $31.29 \%$ (w.b.) at the end of 330 minute drying and $90^{\circ} \mathrm{c}$ temperature moisture content reduced to $25.19 \%$ (w.b.) at the end of 300 minute drying.

Drying characteristics of $0.6 \%$ KMS blanched onion sample (6 $\mathrm{mm}$ size): The initial moisture content of the onion slices was $89.90 \%$ (w.b.).

As shown in figure 12 For $0.6 \%$ KMS blanched onion sample dried at $70^{\circ} \mathrm{C}$ air temperature, moisture content reduced to $34.63 \%$ (w.b.) at the end of 360 minute drying, for the same pretreatment and size, the moisture content at $80^{\circ} \mathrm{C}$ temperature moisture content reduced to $32.44 \%$ (w.b.) at the end of 330 minute drying and $90^{\circ} \mathrm{c}$ temperature moisture content reduced to $24.06 \%$ (w.b.) at the end of 300 minute drying.

\section{Effect of temperature and pretreatments on dehydration ratio}

The rehydration ratio is one of the important parameter showing the bulk reduction in the weight of the onion. High the rehydration ratios better the process of drying. Rehydration ratio refers to the extent of originality in product. From (Fig. 13) it is clear that $0.2 \%$ KMS blanched sample dried at $90^{\circ} \mathrm{C}(6 \mathrm{~mm}$ size $)$ has the lowest rehydration ratio $(0.105)$.

Rehydration ratio for $.2 \%$ KMS blanched sample dried at $70^{\circ} \mathrm{C}(6 \mathrm{~mm}$ size $)$ has the highest rehydration ratio (0.157). Singh et al. (2006) carried out a study on effect of drying conditions on the quality of dehydrated leafy vegetables (amaranth, curry leaves, drumstick leaves, methi and palak) reported that the rehydration ratio was lower in the product rehydrated at high temperature and it was comparatively high in the products dried at low temperature (Fig. 14 and 15).

Rehydration ratio refers to the extent of originality in product reached after the rehydration of Rehydrated product. From (Fig. 16) it is obvious that $0.6 \%$ KMS blanched sample dried at $90^{\circ} \mathrm{C}(2 \mathrm{~mm}$ size $)$ has the highest rehydration ratio (5.71). Rehydration ratio for water blanched sample dried at $70^{\circ} \mathrm{C}(6 \mathrm{~mm}$ size $)$ had the lowest rehydration ratio (4.03).

The least rehydration ratio was observed for the sample without blanching. Singh et al. (2006) conducted a study on effect of drying conditions on the quality of rehydrated leafy vegetables (amaranth, curry leaves, drumstick leaves, methi and palak) and reported that the rehydration ratio was higher in the product rehydrated at high temperature and it was comparatively low in the products dried at low temperature. The statistically analyzed data is tabulated in Appendix A and B (Fig. 17 and 18).

\section{Effect of temperature and pretreatment on the Ascorbic acid (Vitamin C)}

The final vitamin $\mathrm{C}$ content in water blanch Sample is lower than the KMS blanched sample according to figure 19 . In most of the cases ascorbic acid decreased with increasing temperature and time. Similar results were reported by Yadav and Sehgal (1997).

Maximum ascorbic acid found was $8.7170^{\circ} \mathrm{C}$ (6mm size) $0.6 \%$ KMS and minimum ascorbic acid $6.0190^{\circ} \mathrm{C}(2 \mathrm{~mm}$ size $)$ water blanching (Fig. 19).

The vitamin $\mathrm{C}$ content in water blanch sample (2mm size) was $8.01,7.21,6.01$ and $(4 \mathrm{~mm}$ size) $8.08,7.39,6.72$ and $(6 \mathrm{~mm}$ size) 8.15 , $7.46,6.89 \mathrm{mg} / 100 \mathrm{~g}$ at temperature 70,80 , and $90^{\circ} \mathrm{C}$. 
Annexure-A: Effect of tray drying on dehydration ratio of onion sample at different Pretreatments and temperature (2mm, 4mm, $6 \mathrm{~mm}$ size)

\begin{tabular}{|c|c|c|c|c|}
\hline \multirow{2}{*}{ Pretreatments } & \multirow{2}{*}{$\begin{array}{c}\text { Size of } \\
\text { onion } \\
\text { sample } \\
(\mathrm{mm})\end{array}$} & \multicolumn{3}{|c|}{ Temperature $\left({ }^{\circ} \mathrm{C}\right)$} \\
\hline & & $70^{\circ} \mathrm{C}$ & $80^{\circ} \mathrm{C}$ & $90^{\circ} \mathrm{C}$ \\
\hline \multirow{3}{*}{$\begin{array}{c}\text { Water } \\
\text { Blanching }\end{array}$} & 2 & 0.140 & 0.117 & 0.124 \\
\hline & 4 & 0.117 & 0.127 & 0.136 \\
\hline & 6 & 0.121 & 0.130 & 0.133 \\
\hline \multirow[b]{3}{*}{$0.2 \% \mathrm{KMS}$} & 2 & 0.114 & 0.146 & 0.120 \\
\hline & 4 & 0.145 & 0.149 & 0.133 \\
\hline & 6 & 0.157 & 0.152 & 0.105 \\
\hline \multirow[b]{3}{*}{$0.4 \% \mathrm{KMS}$} & 2 & 0.130 & 0.130 & 0.120 \\
\hline & 4 & 0.136 & 0.145 & 0.123 \\
\hline & 6 & 0.144 & 0.147 & 0.135 \\
\hline \multirow[b]{3}{*}{$0.6 \% \mathrm{KMS}$} & 2 & 0.148 & 0.145 & 0.116 \\
\hline & 4 & 0.152 & 0.147 & 0.121 \\
\hline & 6 & 0.154 & 0.149 & 0.133 \\
\hline
\end{tabular}

Annexure-B: Effect of tray drying on Rehydration ratio of onion sample at different Pretreatments and temperature (2mm, $4 \mathrm{~mm}, 6 \mathrm{~mm}$ size)

\begin{tabular}{|c|c|c|c|c|}
\hline \multirow[t]{2}{*}{ Pretreatments } & \multirow{2}{*}{$\begin{array}{c}\text { Size of } \\
\text { onion } \\
\text { sample } \\
(\mathrm{mm})\end{array}$} & \multicolumn{3}{|c|}{ Temperature $\left({ }^{0} \mathrm{C}\right)$} \\
\hline & & $70^{\circ} \mathrm{C}$ & $80^{\circ} \mathrm{C}$ & $90^{\circ} \mathrm{C}$ \\
\hline \multirow{3}{*}{$\begin{array}{c}\text { Water } \\
\text { Blanching }\end{array}$} & 2 & 4.11 & 4.21 & 4.35 \\
\hline & 4 & 4.08 & 4.19 & 4.30 \\
\hline & 6 & 4.03 & 4.14 & 4.21 \\
\hline \multirow[b]{3}{*}{$0.2 \% \mathrm{KMS}$} & 2 & 4.66 & 4.99 & 5.01 \\
\hline & 4 & 4.42 & 4.91 & 4.99 \\
\hline & 6 & 4.31 & 4.72 & 4.89 \\
\hline \multirow[b]{3}{*}{$0.4 \% \mathrm{KMS}$} & 2 & 5.02 & 5.30 & 5.45 \\
\hline & 4 & 5.19 & 5.22 & 5.32 \\
\hline & 6 & 5.16 & 5.19 & 5.23 \\
\hline \multirow[b]{3}{*}{$0.6 \% \mathrm{KMS}$} & 2 & 5.31 & 5.54 & 5.71 \\
\hline & 4 & 5.27 & 5.47 & 5.62 \\
\hline & 6 & 5.21 & 5.32 & 5.44 \\
\hline
\end{tabular}




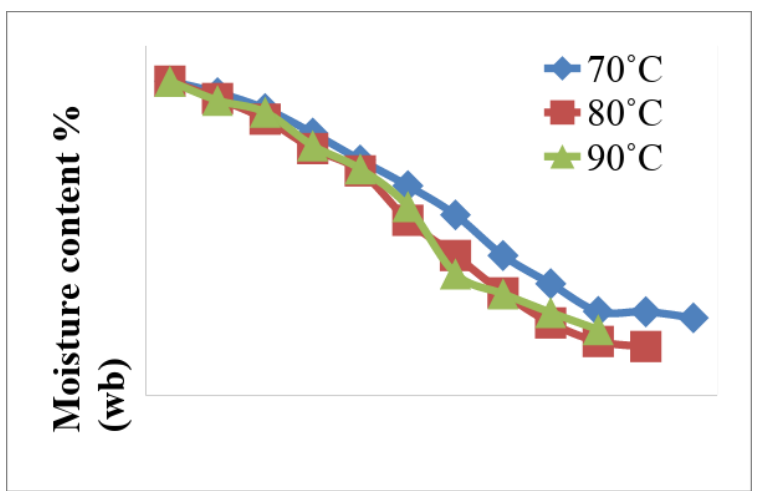

Fig.1 Effect of tray drying on moisture content of water blanched onion sample ( $2 \mathrm{~mm}$ size) dried at different temperature

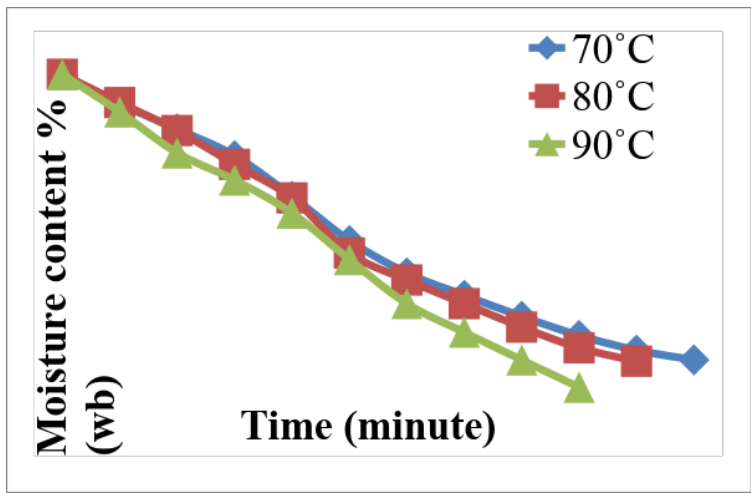

Fig.3 Effect of tray drying on moisture content of $0.4 \%$ KMS blanched onion sample

( $2 \mathrm{~mm}$ size) dried at different temperature

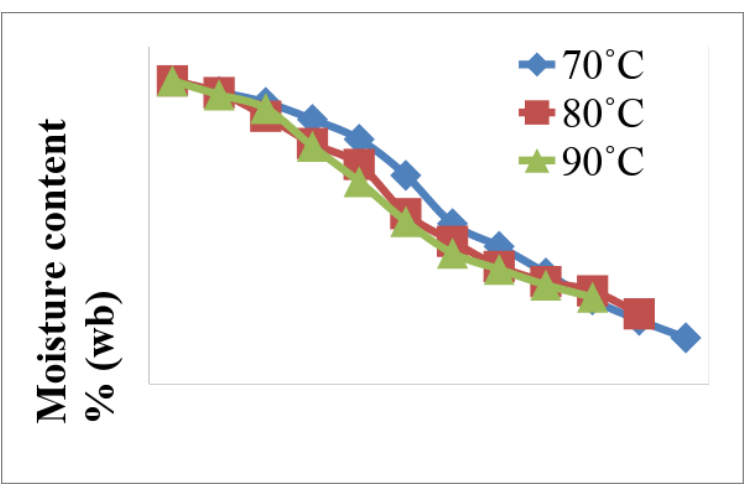

Fig.5 Effect of tray drying on moisture content of water blanched onion sample (4 $\mathrm{mm}$ size) dried at different temperature

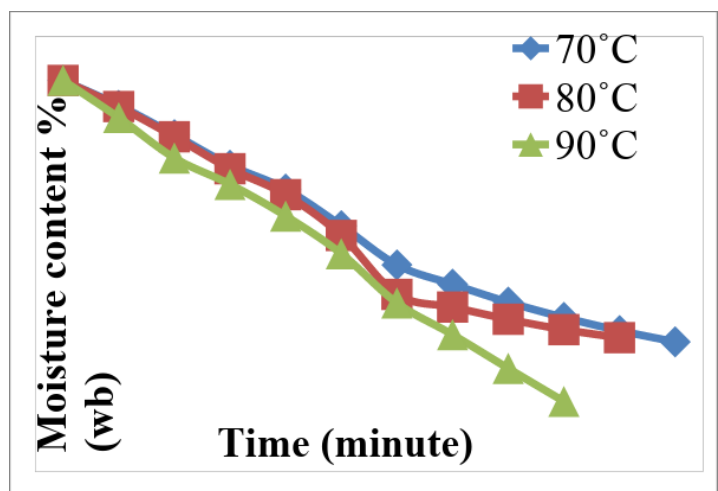

Fig.2 Effect of tray drying on moisture content of $0.2 \%$ KMS blanched onion sample (2mm size) dried at different temperature

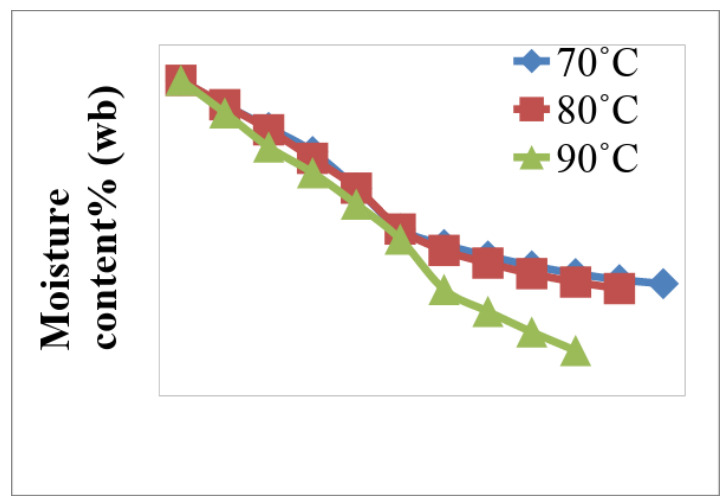

Fig.4 Effect of tray drying on moisture content of $0.6 \%$ KMS blanched onion sample (2mm size) dried at different temperature

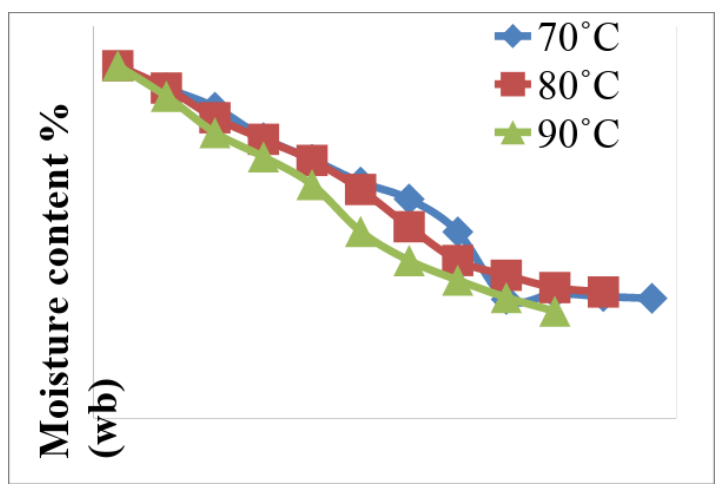

Fig.6 Effect of tray drying on moisture content of $0.2 \% \mathrm{KMS}$ blanched onion sample (4 $\mathrm{mm}$ size) dried at different temperature. 


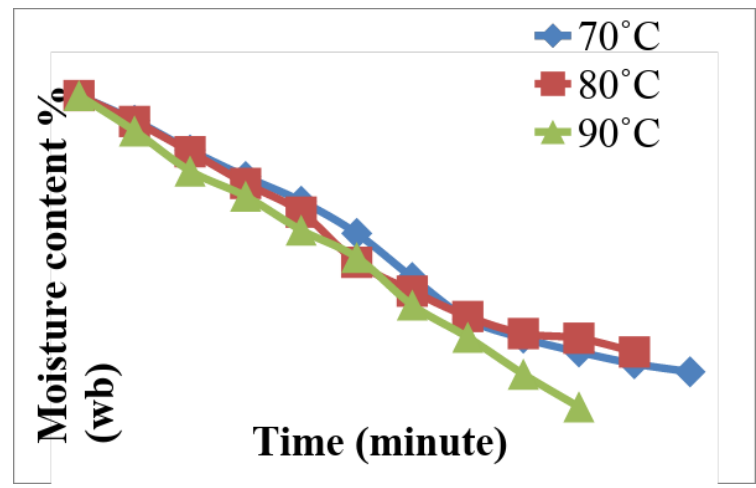

Fig.7 Effect of tray drying on moisture content of $0.4 \%$ KMS blanched onion sample (4 mm size) dried at different

temperature

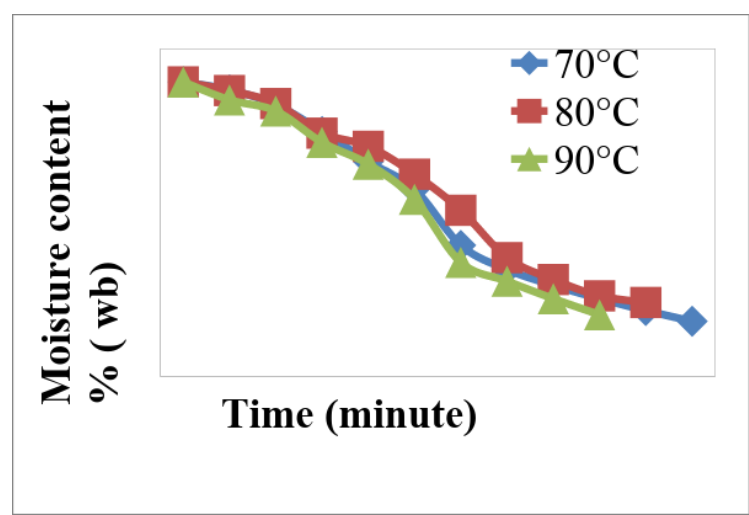

Fig.9 Effect of tray drying on moisture content of water blanched onion sample (6 $\mathrm{mm}$ size) dried at different temperature

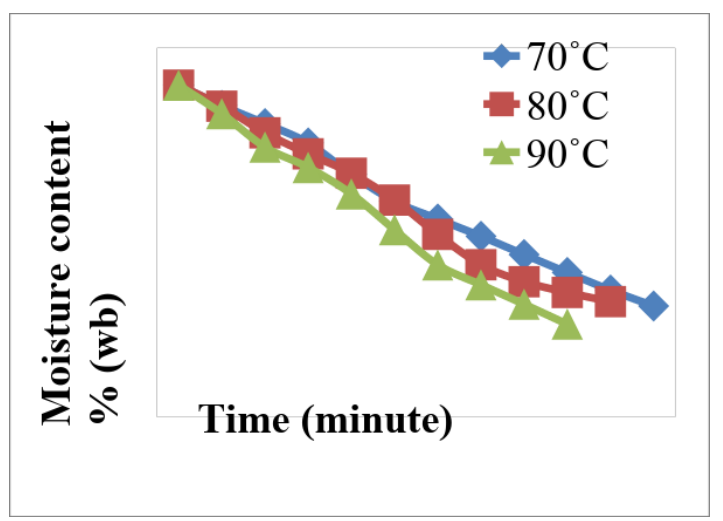

Fig.11 Effect of tray drying on moisture content of $0.4 \%$ KMS blanched onion sample

(6 mm size) dried at different temperature

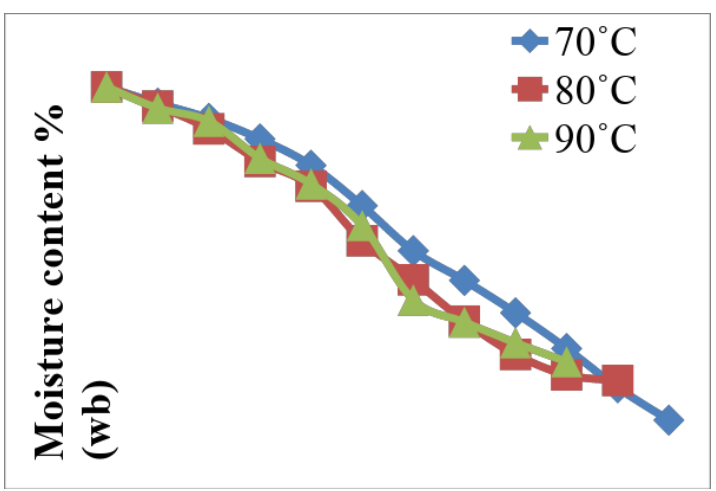

Fig.8 Effect of tray drying on moisture content of $0.6 \%$ KMS blanched onion sample (4 $\mathrm{mm}$ size) dried at different temperature

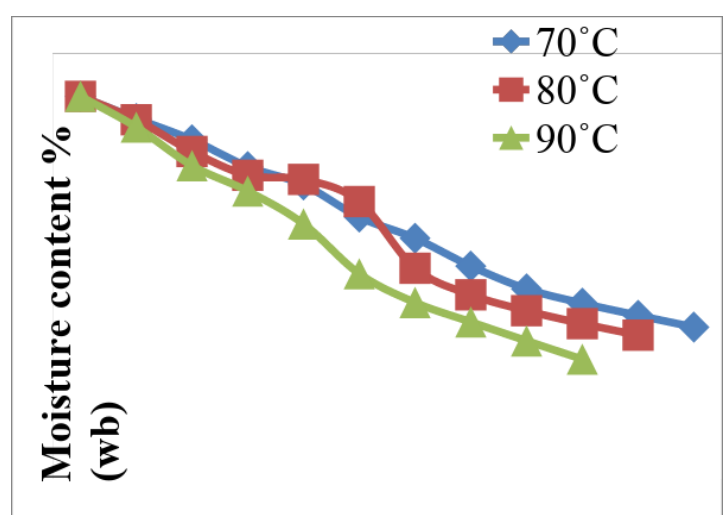

Fig.10 Effect of tray drying on moisture content of $0.2 \%$ KMS blanched onion sample (6 mm size) dried at different temperature

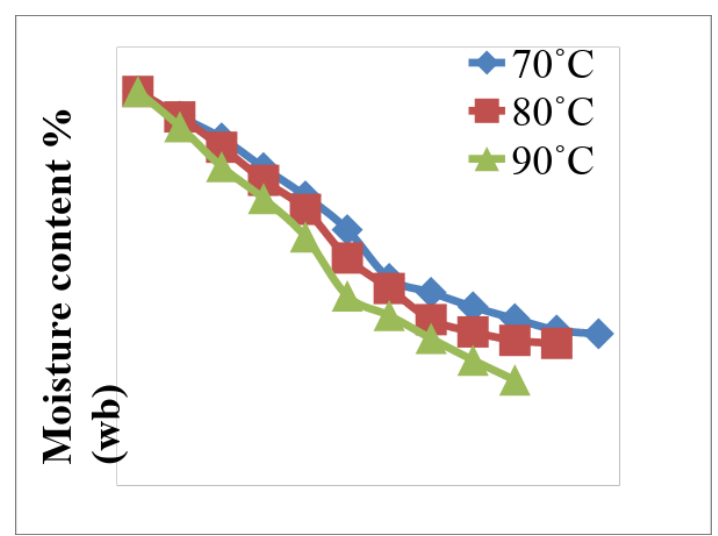

Fig.12 Effect of tray drying on moisture content of $0.6 \%$ KMS blanched onion sample (6 $\mathrm{mm}$ size) dried at different temperature 


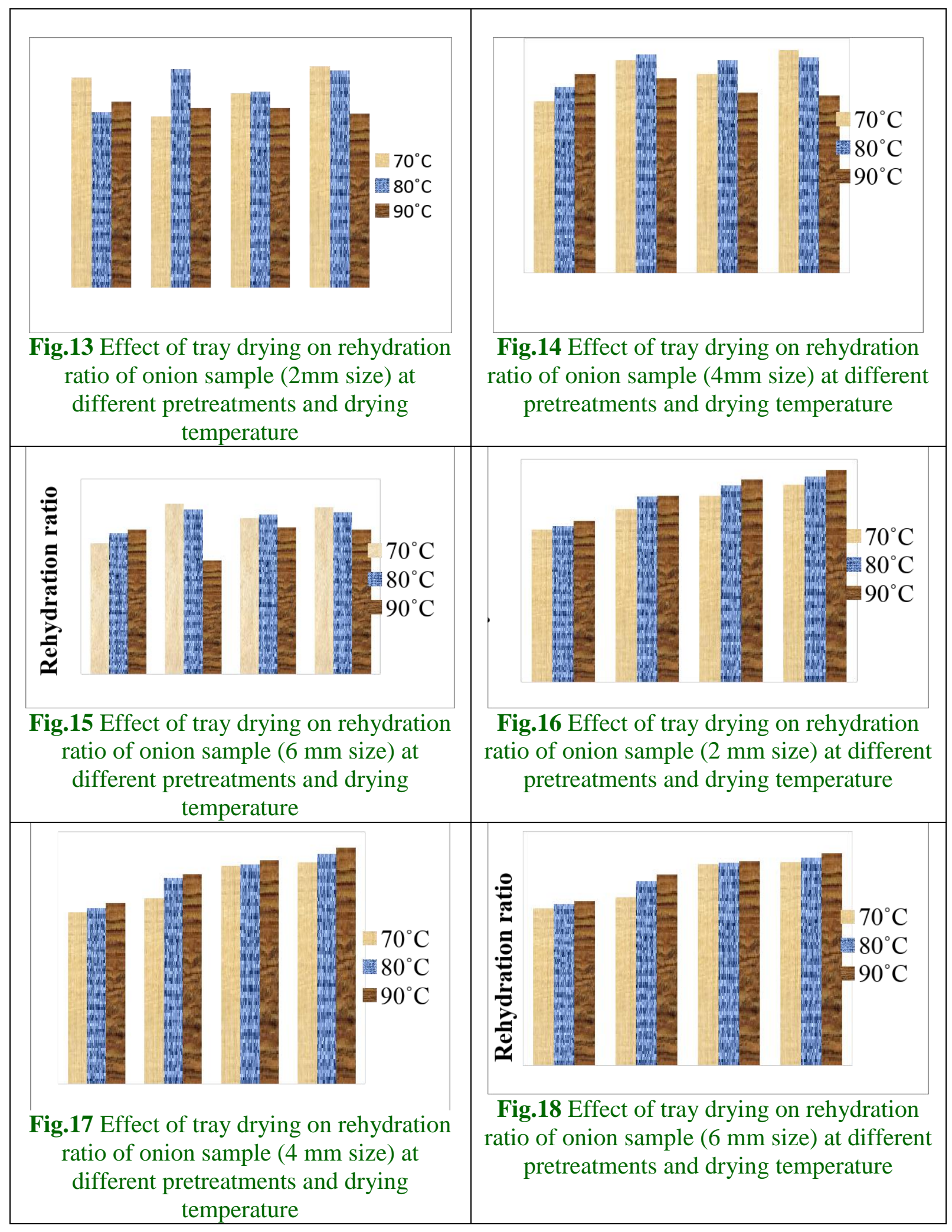




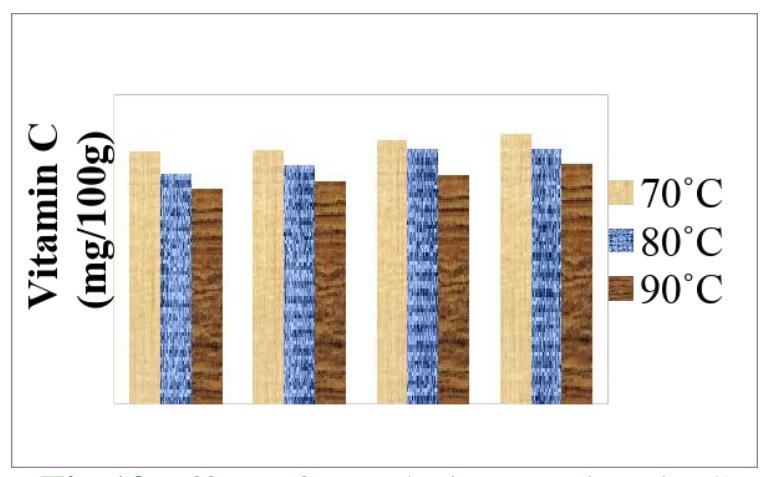

Fig.19 Effect of tray drying on vitamin $\mathrm{C}$ content of onion sample ( $6 \mathrm{~mm}$ size $)$ at different pretreatments and drying temperature

The vitamin $\mathrm{C}$ content in $0.2 \% \mathrm{KMS}$ sample (2mm size) was 8.09, 7.5, 6.95 and (4mm size) $8.11,7.65,7.1$ and (6mm size) 8.19, 7.74, 7.2 $\mathrm{mg} / 100 \mathrm{~g}$ at temperature 70,80 , and $90^{\circ} \mathrm{C}$.

The vitamin $\mathrm{C}$ content in $0.4 \% \mathrm{KMS}$ sample ( $2 \mathrm{~mm}$ size) was $8.31,7.92,7.14$ and (4mm size) $8.42,8.15,7.29$ and (6mm size) $8.53,8.24,7.4$ $\mathrm{mg} / 100 \mathrm{~g}$ at temperature 70,80 , and $90^{\circ} \mathrm{C}$.

The vitamin $\mathrm{C}$ content in $0.6 \% \mathrm{KMS}$ sample (2mm size) was 8.56, 8.03, 7.55 and (4mm size) $8.62,8.11,7.69$ and (6mm size) $8.71,8.23,7.76$ $\mathrm{mg} / 100 \mathrm{~g}$ at temperature 70,80 , and $90^{\circ} \mathrm{C}$.

\section{Effect of temperature and pretreatment on the sugar}

The final sugar content in water blanched sample was lower than the KMS blanched sample according to figure 20 . In most of the cases sugar content decreased with increase in temperature and time. Same results were also reported by Yadav and Sehgal (1997) (Fig. 20).

Maximum reducing sugar was $2.2970^{\circ} \mathrm{C}(6 \mathrm{~mm}$ size) $0.6 \% \mathrm{KMS}$ and minimum reducing sugar was $2.0490^{\circ} \mathrm{C}$ ( $2 \mathrm{~mm}$ size) in water blanching. The reducing sugar content found in water blanched sample (2mm size) was $2.11,2.08$, 2.04 and (4mm size) 2.13, 2.11, 2.06 and $(6 \mathrm{~mm}$ size) $2.16,2.12,2.07 \mathrm{mg} / 100 \mathrm{~g}$ at temperature 70,80 , and $90^{\circ} \mathrm{C}$.

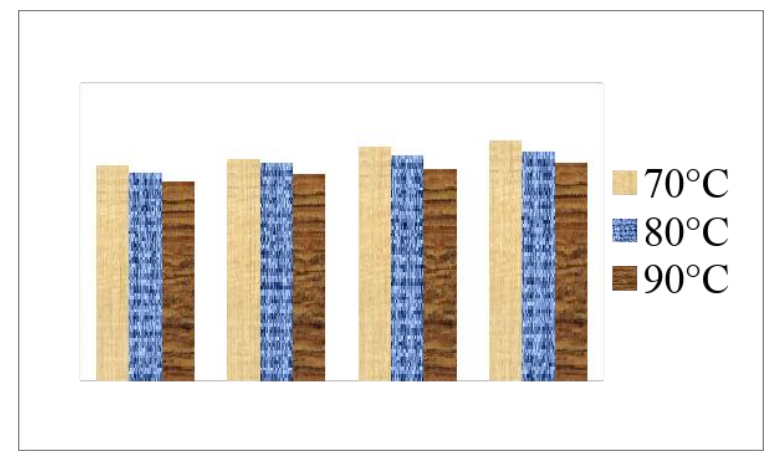

Fig.20 Effect of tray drying on sugar content of onion sample (6mm size) at different pretreatment and drying temperature

The reducing sugar content found in $0.2 \% \mathrm{KMS}$ sample (2mm size) was $2.14,2.12,2.09$ and (4mm size) 2.16, 2.14, 2.1 and (6mm size) 2.19, $2.17,2.11 \mathrm{mg} / 100 \mathrm{~g}$ at temperature 70,80 , and $90^{\circ} \mathrm{C}$

The reducing sugar content in $0.4 \% \mathrm{KMS}$ sample (2mm size) was $2.17,2.14,2.11$ and (4mm size) 2.23, 2.19, 2.13 and (6mm size) $2.26,2.23,2.14 \mathrm{mg} / 100 \mathrm{~g}$ at temperature 70,80 , and $90^{\circ} \mathrm{C}$.

The reducing sugar content in $0.6 \% \mathrm{KMS}$ sample (2mm size) was 2.23, 2.18, 2.13 and for $4 \mathrm{~mm}$ size it was $2.25,2.21,2.15$ and for $6 \mathrm{~mm}$ size it was 2.29, 2.23, $2.17 \mathrm{mg} / 100 \mathrm{~g}$ at temperature 70,80 , and $90^{\circ} \mathrm{C}$.

\section{Sensory evaluation}

Sensory attributes are one of the most important attributes of foods both for its aesthetic value and quality judgment, and it may easily change if not properly protected, some important parameters like colour, texture, taste, flavour and over all acceptability play an important role in quality judgment of any food material. Bajaj et al., (1993) evaluated culinary quality of blanched and rehydrated fenugreek leaves. Color, texture and overall quality of blanched leaves received significantly higher scores than unblanched leaves. 


\section{Overall acceptability}

The overall acceptability score for all the pretreatments at three temperatures. It was observed that drying with KMS blanching pretreatment is most efficient than other pretreatments for the retention of Overall acceptability of dried onion sample. Total score obtained for Overall acceptability on the basis of sensory evaluation was found higher in drying of onion sample $0.4 \% \mathrm{KMS}$ pretreatment and the sample dried at $70^{\circ \mathrm{C}}(4 \mathrm{~mm}$ size $)$ and maximum texture score (7.39).

In conclusion, experiments were conducted to study the tray drying characteristics of Onion slices and preparation of onion powder. Studies were also carried out to investigate the effect of treatment on drying characteristics of onion slices and quality parameters of onion powder just after preparation and storage. Fresh onion was procured from local market. Onion were cleaned, washed, peeled, sliced and blanched with KMS solution. After blanching the onion slices were dried in tray dryer at different temperature. After drying, the slices were grind in grinder and sieved through Mesh screen and packed in LPDE bags. The physiochemical and sensory qualities were evaluated just after preparation of onion powder. On the basis of present investigation the following conclusions could be drawn.

Drying rate of onion in tray dryer was affected by hot air temperature.

Higher drying rate at initial stage of drying decreases with time suggests decrease in moisture content with the passage of time.

The least final moisture content \% (w.b.) was found for water blanching (12.17) at $90^{\circ} \mathrm{C}$ for $2 \mathrm{~mm}$ size and maximum final moisture content $\%$ (w.b.) was found for $0.2 \% \mathrm{KMS}$ blanched $70^{\circ} \mathrm{C} 6 \mathrm{~mm}$ size (35.67).

The drying rate of onion slices under tray drying decreased as the drying time progressed and finally attained zero drying rates.

Low the rehydration ratio betters the process of drying. It is clear that $0.2 \% \mathrm{KMS}$ blanched sample dried at $90^{\circ} \mathrm{C}(6 \mathrm{~mm}$ size $)$ has the lowest rehydration ratio $(0.105)$. Rehydration ratio for $0.2 \% \mathrm{KMS}$ blanched sample dried at $70^{\circ} \mathrm{C}$ $(6 \mathrm{~mm}$ size $)$ has the highest rehydration ratio (0.157).

Higher the rehydration ratio better is the quality of the product. Rehydration ratio refers to the extent of originality in product reached after the rehydration of rehydrated product. It is clear that $0.6 \% \mathrm{KMS}$ blanched sample dried at $90^{\circ} \mathrm{C}$ ( $2 \mathrm{~mm}$ size) has the highest rehydration ratio (5.71). Rehydration ratio for water blanched sample dried at $70^{\circ} \mathrm{C}(6 \mathrm{~mm}$ size $)$ has the lowest rehydration ratio (4.03).

The final vitamin $\mathrm{C}$ content in water blanched Sample is lower than the KMS blanched sample. In most of the cases ascorbic acid decreases with increasing temperature and time. Maximum ascorbic acid found $8.7170^{\circ} \mathrm{C}(6 \mathrm{~mm}$ size) $0.6 \% \mathrm{KMS}$ and minimum ascorbic acid found $6.0190^{\circ} \mathrm{C}$ ( $2 \mathrm{~mm}$ size) water blanching.

The final sugar content in water blanched Sample is lower than the KMS blanched sample. In most of the cases sugar decreases with increasing temperature and time. Maximum reducing sugar found $2.2970^{\circ} \mathrm{C}$ (6mm size) $0.6 \% \mathrm{KMS}$ and minimum reducing sugar found $2.0490^{\circ} \mathrm{C}(2 \mathrm{~mm}$ size $)$ water blanching.

Total score obtained for Overall acceptability evaluation on the basis of sensory evaluation was found higher in drying of onion sample $0.4 \% \mathrm{KMS}$ pretreatment and the sample dried at $70^{\circ} \mathrm{C}$ (4mm size) Maximum OA score (7.39).

\section{References}

Ahmad, N. (1997) Researched and Development Conference on Vegetables. The Market and the producer. ACTA. Horticulture.

AOAC (1990) Official methods of Analysis, $15^{\text {th }}$ edn. Association of Official Analytical Chemist, Washington, DC.

Anonymous., Pandey (1994) Post harvest losses Research Digest. AMRP in Post-Harvest Technology (1980-90), Gujarat Agricultural University, Junagarh, India p-9.

Azzous, S., Guizani, A., Jomaa, W., Belghith, 
A. (2002) Moisture diffusivity and drying kinetics equation of conventional drying of grapes, J. Of Food Engg., vol.55: 23.

Bates, A.W., and Roberts, J.S. (2001) The utilization of apple pomace as a press aid in fruit juicing. In: IFT annual meetingNew Orleans, Louisiana: session 88E, Fruit and Vegetable Products: Processing.

Block, E., Ahmad, S., Catalfamo, C.R. (1986) Antithrombotic organ sulfur compound from onion and garlic: structural, mechanistic, and synthetic studies. $J$. of American chemical society, 108; pp. 7045.

Bajaj, M., Aggarwal, P., Minhas, K.S. and Sidhu, J. S. (1993) Effect of blanching treatments on the quality characteristics of dehydrated fenugreek leaves. J. Food Sci. Tech., 30 (3): 196-198.

Furhath, K. (1997) Antioxidative activity of sulfur -containing flavor compound in onion. Bioscience Biotech. And Biochemistry, 61: 1482.

Kim, J.Y. (2002) Allinase independent inhibition of staphylococcus by heated onion and garlic. J. of food science, 67(2):780.

Krest, I., Glodec, J., (2000). Cysteine slfoxide and allinase activity of onion and alliums pp. J. of Food Agri. and Food Chemistry, 48: 3753.

Ranganna, S. (1986) Handbook of analysis and quality control for fruit and vegetable products, Tata McGraw Hill Pub. New Delhi : 441-496, 112.

Rivlin R. (2001) Historical perspective on the use of onion and garlic. J Nutr.. 2001; 131 pp. $95,15-45$

Shekhada, V.P. (1996) Effect of plant growth regulators on growth yield and quality of onion (Allium cepa L.) CV Junagadh local (Pilli Patti), M.Sc. Unpublished thesis, College of Agriculture, Gujarat Agricultural University, Junagadh, India.

Siems, W.G., Sehrat, T., Behrend,H.(1996) Influence of Allium on oxidative stress status: A clinical investigation .In Proceeding of the international symposium on natural antioxidant. pp188.

Singh, U., Sagar V. R., Behera, T. K., Suresh Kumar P. (2006) Effect of drying conditions on the quality of dehydrated selected leafy vegetables. J. Food Sci. Tech., 43 (6): 579-582.

Yadav, S. K. and Sehgal, S. (1997) Effect on home processing on ascorbic acid, sugar and beta - carotene content of amaranthus and spinach leaves. Plant Food for Human Nutrition. 47 (2), 25 - 131.

\section{How to cite this article:}

Ravi Dutt Shukla, Anurag Patel and Avanish Kumar. 2019. Tray Drying Characteristics of Onion Slices and Physicochemical Analysis of Dried Onion Powder. Int.J.Curr.Microbiol.App.Sci. 8(04): 2468-2483. doi: https://doi.org/10.20546/ijcmas.2019.804.288 